\title{
PENGEMBANGAN LKS ILMU PENGETAHUAN ALAM KELAS 4 MELALUI PENDEKATAN INTEGRASI AL-ASMA' AL-HUSNA
}

\author{
Alfan Nur Azizi \\ UIN Maulana Malik Ibrahim Malang \\ e-mail: alfannurazizi@uin-malang.ac.id
}

Diterima: 27 April 2021 I Direvisi: 12 Agustus 2021 I Disetujui: 11 Oktober 2021 (C) 2021 Pendidikan Guru Madrasah Ibtidaiyah Fakultas Agama Islam Universitas Islam Malang

\begin{abstract}
Abstrak
Pengembangan LKS Ilmu Pengetahuan Alam melalui pendekatan integrasi Al-Asma' Al-Husna ini berdasarkan pada kebutuhan akan LKS yang terintegrasi dengan Al-Asma' Al-Husna sebagai salah satu sumber belajar peserta didik. Tujuan dari penelitian ini adalah untuk menghasilkan LKS Ilmu Pengetahuan Alam untuk kelas 4 yang dikembangkan melalui pendekatan integrasi Al-Asma' AlHusna. Penelitian ini dilaksanakan dengan menggunakan metode Penelitian dan Pengembangan (Research and Development). Pengembangan LKS ini, berdasarkan pada penilaian oleh ahli materi memperoleh hasil dengan kualifikasi baik, pada penilaian oleh ahli desain juga memperoleh hasil kualifikasi baik. Penilaian kemenarikan oleh peserta didik menunjukkan hasil bahwa LKS tersebut menarik. Sedangkan hasil uji coba dilakukan dengan metode pre-test dan post-test yang menunjukkan pengaruh yang positif. Secara keseluruhan, LKS ini layak dalam hal materi dan desain untuk digunakan peserta didik kelas 4 dan efektif dalam meningkatkan prestasi belajar peserta didik.
\end{abstract}

Kata kunci: Pengembangan, LKS, Pendekatan Integrasi Al-Asma'Al-Husna.

\begin{abstract}
The development of students' worksheets of science with Al-Asma' Al-Husna approach was based on the need for students' worksheets with Al-Asma' Al-Husna integration as one of students' learning resources. This research aims to fulfill student worksheets' availability to increase elementary school students' effectiveness. The purpose of this research was to produce students' worksheets of science for $4^{\text {th }}$ grade by Al-Asma' Al-Husna integration approach. This study used the development research method. According to the validators' assessment, the results of validation by matter experts was in good qualifications, the result of validation by design expert was also in good qualifications. The attractiveness assessment by students shows the results that the students' worksheet was interesting. Meanwhile, the test results were carried out using the pre-test and post-test methods which showed a positive effect. Overall, the science students' worksheets were included in both qualifying so fit for science teaching for fourth grade in elementary school.
\end{abstract}

Key words: Developing, Students' Worksheet, Al-Asma' Al-Husna Approach.

\section{PENDAHULUAN}

Tingkat keberhasilan pembelajaran dapat ditunjukkan dengan ketercapaian prestasi belajar oleh peserta didik. Hal ini sebagaimana telah disampaikan 
bahwasanya prestasi belajar menunjukkan tingkat kesuksesan peserta didik dalam memahami materi pembelajaran (Hamdu \& Agustina, 2011). Dalam hal ini, tercapainya prestasi belajar merupakan tujuan dilaksanakannya pembelajaran.

Penilaian prestasi belajar peserta didik adalah sebuah proses dalam menentukan kompetensi peserta didik dalam mencapai tujuan pembelajaran (Saleh \& Kim, 2009). Sehingga, untuk mencapai tujuan pendidikan dengan baik, maka caranya adalah dengan meningkatkan prestasi belajar peserta didik.

Ketersediaan sumber belajar yang menarik dan efektif merupakan salah satu faktor yang dapat berpengaruh terhadap prestasi belajar peserta didik. Penelitian yang telah dilakukan oleh Heynemans pada tahun 1981, menyatakan bahwa ketersediaan buku teks dan sumber belajar yang lainnya pada sekolah sangat mempengaruhi prestasi belajar di sekolah (Nannyonjo, 2007). Dengan demikian, ketersediaan sumber belajar merupakan hal yang sangat penting untuk dipenuhi di sekolah-sekolah.

Berdasarkan hasil pengamatan yang telah dilakukan terhadap beberapa sumber belajar yang telah beredar di sekolah-sekolah, banyak terdapat kekurangan, di antaranya (1) materi yang sangat singkat, (2) materi tidak terperinci, (3) kurangnya contoh yang konkret dalam bentuk visual, (4) tampilan LKS yang kurang menarik bagi peserta didik. Dengan beberapa kekurangan tersebut, maka pengembangan terhadap LKS perlu dilakukan dalam meningkatkan prestasi belajar peserta didik.

LKS adalah lembaran yang berisi kumpulan materi, ringkasan, dan tugas yang harus diselesaikan oleh peserta didik (Anggraini, Wahyuni, \& Lesmono, 2016). LKS dapat memuat lembar praktikum, ringkasan materi, petunjuk untuk melakukan proyek, dan lain sebagainya (Sadjati, 2012).

LKS merupakan sumber belajar yang mana guru dapat menyusun dan mengembangkan sendiri (Widjajanti, 2008). Guru sebagai fasilitator dalam pembelajaran dapat menyusun LKS secara mandiri sebagai panduan dalam melaksanakan pembelajaran di kelas.

LKS selain sebagai sumber belajar utama bagi peserta didik, juga dapat digunakan sebagai penunjang dari sumber belajar yang lain. Hal ini menunjukkan bahwa LKS juga dapat digunakan sebagai media pembelajaran sesuai dengan kegiatan pembelajaran yang telah direncanakan oleh guru dalam Rencana Pelaksanaan Pembelajaran (Widjajanti, 2008).

Di samping itu, LKS juga dapat menjadi stimulus yang tertulis bagi guru dalam menyajikan pembelajaran. Oleh karena itu penyajiannya, perlu 
memperhatikan kriteria media grafis sebagai media visual dalam menarik perhatian peserta didik sebagai pembaca (Fannie \& Rohati, 2014).

Selain pemahaman tentang konsep-konsep yang sains yang telah disajikan dalam LKS, peserta didik perlu memahami konsep keimanan. LKS ini dikembangkan secara integratif terhadap Al-Asma' Al-Husna. Konsep keimanan dalam LKS ini ditampakkan dengan adanya perpaduan sains dan Al-Asma' AlHusna.

Melalui materi yang terintegrasi dengan Al-Asma' Al-Husna, peserta didik dapat mempelajari dua konsep sekaligus, yakni konsep sains dan konsep keislaman. Kedua konsep tersebut merupakan langkah untuk mengenal Allah sebagai Tuhan dan sebagai pencipta alam semesta. Latifah menyatakan bahwa salah satu cara yang dapat membantu manusia dalam mengenal Tuhan adalah sains (Latifah, Hidayah, Shawmi, Amrullah, \& Fitriana, 2019).

Di samping mengenal Allah melalui sains, menurut Saiful Bahri, salah satu cara lain untuk mengenal Allah adalah melalui nama-nama Allah (Al-Asma' AlHusna). Al-Asma' Al-Husna merupakan perantara komunikasi yang digunakan oleh Allah SWT agar manusia bisa beriman kepada-Nya (Bahri \& Nidal, 2019).

Pengintegrasian tersebut perlu dilakukan untuk mengenalkan Al-Asma' AlHusna secara esensial kepada para peserta didik. Sebab pada saat ini banyak permasalahan yang terjadi pada kalangan umat Muslim yang berkaitan dengan AlAsma' Al-Husna, di antaranya banyak yang tidak dapat menghafalkan 99 Al-Asma' Al-Husna (Rosmani \& Zakaria, 2018).

Dengan demikian, peneliti melakukan pengembangan dalam rangka menghasilkan LKS IPA untuk kelas 4 yang dikembangkan melalui pendekatan integrasi Al-Asma' Al-Husna. Pengembangan pada LKS dilakukan pada satu pokok bahasan, yaitu pada pokok bahasan Bumi dan Alam Semesta.

\section{METODE}

Penelitian ini dilakukan dengan menerapkan metode penelitian pada jenis Penelitian dan Pengembangan (Research and Development). Penelitian dan pengembangan adalah metode penelitian yang dilaksanakan dalam rangka menghasilkan sebuah produk dan menguji coba tingkat efektivitas produk tersebut (Sugiyono, 2009). Adapun pengembangan produk yang dilakukan dalam Reasearch and Development (R\&D) adalah untuk menghasilkan produk yang baru atau menyempurnakan produk yang sudah ada (Sukmadinata, 2008). Dalam penelitian ini, peneliti mengembangkan sebuah produk yang divalidasi dan uji 
coba efektivitas produk tersebut dengan melakukan eksperimen terhadap subjek penelitian. Peneliti melakukan perbaikan terhadap produk yang lama.

Pendekatan pada penelitian ini adalah pendekatan kuantitatif. Hal ini dikarenakan penelitian ini menguji pengaruh penggunaan produk dalam meningkatkan prestasi belajar peserta didik dengan metode eksperimen dan data yang disajikan adalah data numerik (Setyosari, 2016).

Model pengembangan yang digunakan dalam penelitian ini adalah desain pengembangan yang dirancang oleh Walter Dick dan Lou Carey. Tahapan desain tersebut, antara lain: (a) identifikasi tujuan pembelajaran, (b) analisis pembelajaran, (c) identifikasi perilaku awal dan karakteristik, (d) perumusan tujuan khusus pembelajaran, (e) pengembangan butir tes acuan kriteria, (f) pengembangan strategi pembelajaran, (g) pengembangan dan pemilihan bahan pembelajaran, (h) perancangan dan pelaksanaan evaluasi formatif, (i) revisi bahan pembelajaran, (j) pendesainan dan pelaksanaan evaluasi sumatif (Pribadi, 2010).

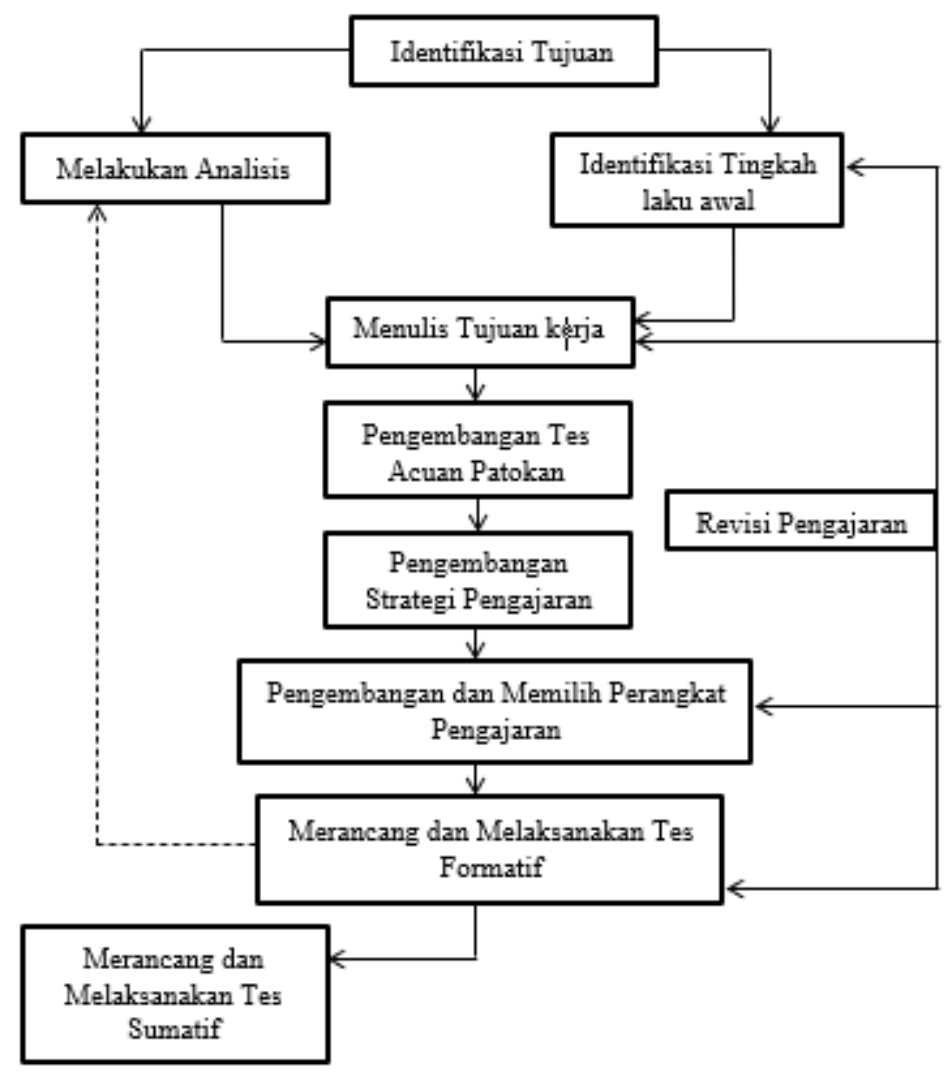

Gambar 1. Tahapan Desain Pengembangan Dick and Carey 


\section{HASIL DAN PEMBAHASAN}

\section{Deskripsi LKS IPA melalui pendekatan integrasi Al-Asma' Al-Husna}

LKS Ilmu Pengetahuan Alam melalui pendekatan integrasi Al-Asma' Al-Husna terdiri atas 5 bagian. Adapun kelima bagian tersebut yaitu: (1) pra pendahuluan, (2) pendahuluan, (3) isi, (4) pelengkap, dan (5) penutup. Secara umum, bagianbagian tersebut sama dengan LKS dan bahan ajar yang lain yang memuat (1) pra materi, (2) materi, dan (3) pasca materi (Tarigan, Agung, \& Parmiti, 2019).

Bagian pra pendahuluan merupakan bagian yang terdapat pada LKS sebelum masuk dalam pembelajaran. Bagian ini terdiri dari sampul depan, kata pengantar, daftar isi, serta rincian SK, KD, dan indikator pencapaian pembelajaran.

Sampul depan yang ditampilkan pada halaman terdepan dari LKS memuat judul "Pesona Semesta di Balik Al-Asma' Al-Husna”, pengguna LKS "untuk kelas IV SD/MI semester 2", nama penyusun LKS "Alfan Nur Azizi”. Sampul depan LKS memiliki latar belakang yang bergambar bumi dan tulisan 2 Al-Asma' Al-Husna. Hal ini ditampilkan sebagai representasi dari judul dan isi pada LKS.

Adapun halaman setelah sampul depan memuat kata pengantar. Kata pengantar disajikan sebagai penjelasan penyusun terhadap gambaran umum isi LKS, ungkapan terima kasih dan harapan penyusun terhadap LKS pada masa depan, dan permohonan kritik dan saran penyusun terhadap pembaca guna penyempurnaan LKS. Kata pengantar pada LKS disajikan setelah sampul depan.

Halaman berikutnya adalah penyajian daftar isi. Daftar isi merupakan daftar dari seluruh judul dan sub judul yang disajikan dalam LKS dan dilengkapi dengan nomor halaman pada masing-masing judul dan sub judul tersebut. Hal ini untuk memudahkan pembaca dalam menemukan judul atau sub judul yang hendak dibaca.

Setelah ditampilkan daftar isi, selanjutnya adalah penyajian rincian SK, KD, dan indikator. Rincian SK, KD, dan indikator disusun untuk menunjukkan SK dan KD yang memuat sebagaimana yang disajikan pada LKS dan indikator yang menunjukkan ketercapaian peserta didik telah mencapai ketuntasan pada pembelajaran yang dimuat pada SK dan KD tersebut. Komponen ini disajikan setelah daftar isi. Adapun tampilan bagian pra pendahuluan adalah sebagai berikut. 

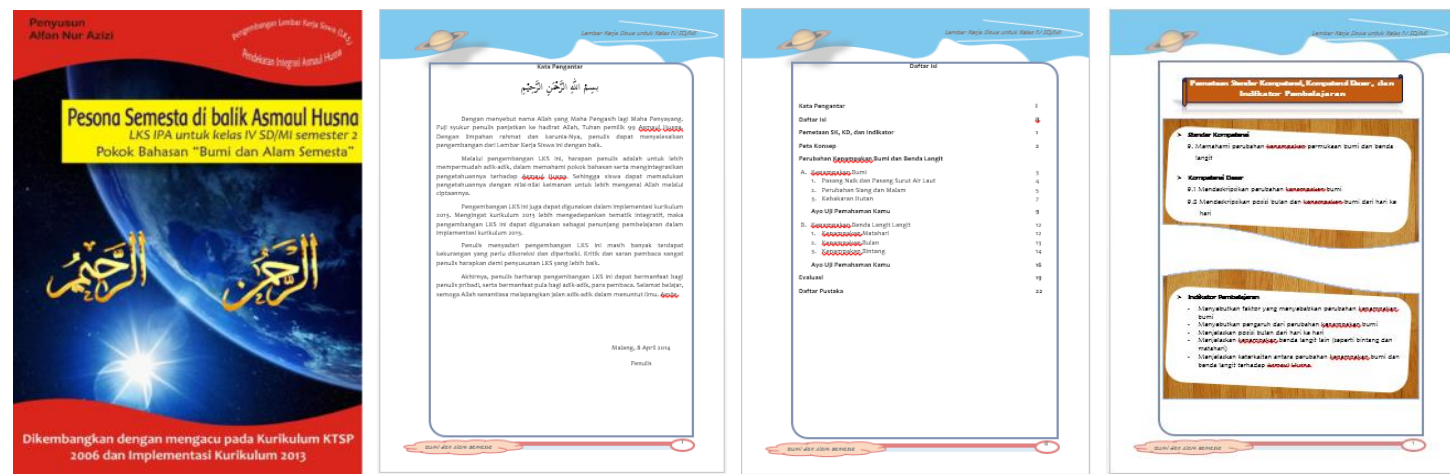

Gambar 2. Bagian Pra Pendahuluan Meliputi Sampul depan, Kata Pengantar, Daftar Isi, dan Rincian SK, KD, dan Indikator

Sebelum masuk pada bagian isi materi, pada LKS ini terdapat bagian pendahuluan. Bagian ini disusun untuk menyajikan informasi tentang materi yang dipelajari. Bagian ini hanya terdiri atas penyajian peta konsep.

Peta konsep merupakan diagram yang memuat konsep-konsep sebagai representasi dari isi materi pembelajaran. Peta konsep pada LKS disajikan untuk memudahkan peserta didik dalam membangun apersepsi sebelum memulai pembelajaran. Peta konsep disusun secara berjenjang dari yang bersifat umum kepada yang lebih khusus yang disajikan dengan garis penghubung. Berikut ini adalah tampilan bagian pendahuluan yang memuat peta konsep.

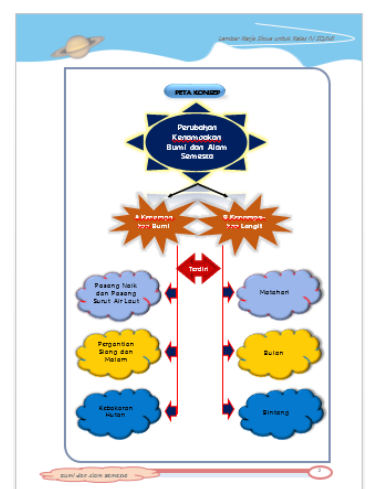

Gambar 3. Bagian Pendahuluan Memuat Peta Konsep

Bagian ketiga dari LKS adalah bagian isi materi. Bagian isi pada LKS memuat seluruh bahasan materi pembelajaran. Materi pada bagian ini disajikan dengan teks penjelasan konsep dan dilengkapi dengan gambar ilustrasi untuk memudahkan peserta didik dalam memvisualisasikan konsep yang dipelajari. 

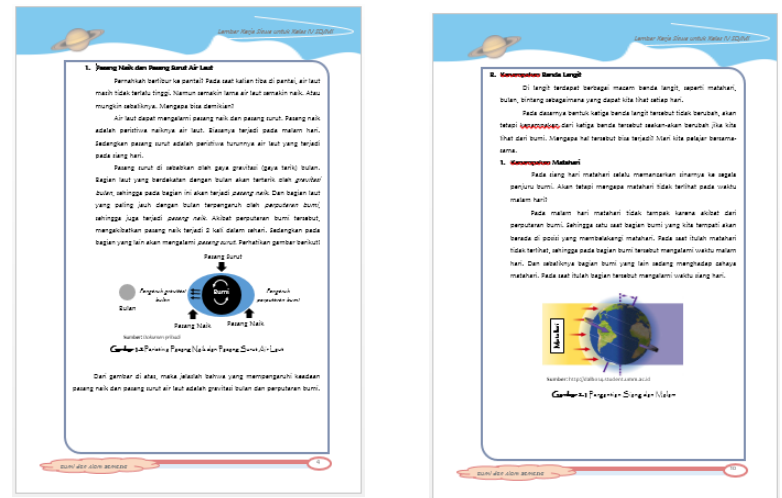

Gambar 4. Bagian Isi Memuat Materi Pembelajaran

Selain materi, LKS juga dilengkapi dengan bagian pelengkap. Bagian ini menyajikan pengetahuan tambahan yang terkait dengan materi yang disajikan secara singkat. Bagian ini terdiri atas 2 komponen, yaitu (1) Tahukan Kamu?, dan (2) Mari Kita Renungkan!.

Pada komponen Tahukah Kamu?, terdapat informasi yang memiliki menyajikan keterkaitan antara materi dan Al-Asma' Al-Husna yang sesuai dengan konsep dalam materi. Tujuan penyajian komponen ini adalah memberikan wawasan integratif kepada peserta didik tentang keterkaitan antara materi dan nama-nama Allah. Sedangkan pada komponen Mari Kita Renungkan!, terdapat informasi tambahan yang memuat keterkaitan materi terhadap ayat Al-Qur'an. Komponen inn ditambahkan sebagai bahan renungan peserta didik setelah mempelajari konsep dan keterkaitannya dengan AlQur'an. Berikut adalah tampilan bagian pelengkap yang memuat (1) Tahukah Kamu? dan (2) Mari Kita Renungkan!.
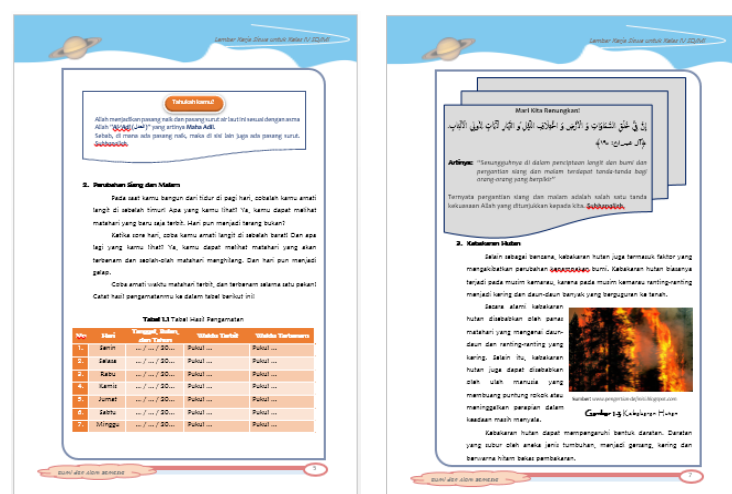

Gambar 5. Bagian Pelengkap Memuat (1) Tahukah Kamu?, dan (2) Mari Kita Renungkan! 
Bagian terakhir pada LKS adalah bagian penutup. Bagian ini terdiri dari daftar pustaka yang merupakan sumber acuan dalam penyusunan LKS. Adapun tampilan bagian penutup pada LKS adalah sebagai berikut.

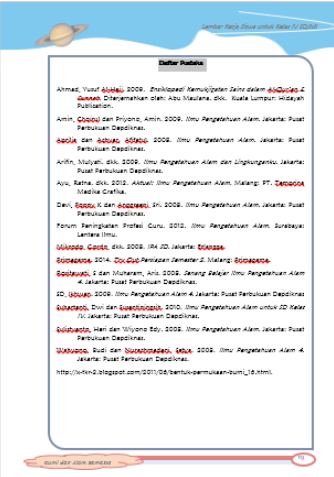

Gambar 6. Bagian Penutup Memuat Daftar Pustaka

\section{Uji Kelayakan LKS IPA dengan Pendekatan Al-Asma' Al-Husna}

LKS yang telah dikembangkan selanjutnya divalidasi untuk memastikan tingkat validitas dalam aspek kelayakan, baik dalam segi materi maupun desain. Hal ini harus dilaksanakan sebelum LKS digunakan sebagai sumber belajar.

Adapun hasil penilaian oleh ahli materi terhadap lembar kerja peserta didik IPA sebagaimana pada tabel berikut berikut:

\begin{tabular}{|c|c|c|c|c|c|c|}
\hline \multirow[t]{2}{*}{ No. } & \multirow[t]{2}{*}{ Kriteria } & \multicolumn{2}{|c|}{ Skor } & \multirow{2}{*}{$\begin{array}{l}P \\
(\%)\end{array}$} & \multirow[t]{2}{*}{ Interpretasi } & \multirow[t]{2}{*}{ Ket. } \\
\hline & & $\mathbf{X}$ & $\mathbf{X}_{1}$ & & & \\
\hline 1 & $\begin{array}{l}\text { Bagaimanakah rumusan topik pada } \\
\text { pengembangan LKS Ilmu Pengetahuan Alam ini? }\end{array}$ & 4 & 4 & 100 & Valid & $\begin{array}{l}\text { Tidak } \\
\text { Revisi }\end{array}$ \\
\hline 2 & $\begin{array}{l}\text { Bagaimanakah kesesuaian materi yang disajikan } \\
\text { pada pengembangan LKS Ilmu Pengetahuan } \\
\text { Alam ini? }\end{array}$ & 4 & 4 & 100 & Valid & $\begin{array}{l}\text { Tidak } \\
\text { Revisi }\end{array}$ \\
\hline 3 & $\begin{array}{l}\text { Apakah rumusan indikator dalam LKS disajikan } \\
\text { dengan rumusan Kompetensi Dasar yang telah } \\
\text { ditetapkan dalam KTSP 2006? }\end{array}$ & 4 & 4 & 100 & Valid & $\begin{array}{l}\text { Tidak } \\
\text { Revisi }\end{array}$ \\
\hline 4 & $\begin{array}{l}\text { Bagaimanakah relevansi Standar Kompetensi } \\
\text { dengan indikator pada LKS Ilmu Pengetahuan } \\
\text { Alam ini? }\end{array}$ & 4 & 4 & 100 & Valid & $\begin{array}{l}\text { Tidak } \\
\text { Revisi }\end{array}$ \\
\hline 5 & $\begin{array}{l}\text { Apakah isi pembelajaran dalam LKS sesuai } \\
\text { dengan KTSP 2006? }\end{array}$ & 4 & 4 & 100 & Valid & $\begin{array}{l}\text { Tidak } \\
\text { Revisi }\end{array}$ \\
\hline 6 & $\begin{array}{l}\text { Bagaimanakah sistematik uraian isi } \\
\text { pembelajaran dalam LKS Ilmu Pengetahuan } \\
\text { Alam ini? }\end{array}$ & 4 & 4 & 100 & Valid & $\begin{array}{l}\text { Tidak } \\
\text { Revisi }\end{array}$ \\
\hline 7 & $\begin{array}{l}\text { Bagaimanakah ruang lingkup materi yang } \\
\text { disajikan dalam LKS Ilmu Pengetahuan Alam } \\
\text { ini? }\end{array}$ & 3 & 4 & 75 & Valid & $\begin{array}{l}\text { Tidak } \\
\text { Revisi }\end{array}$ \\
\hline 8 & $\begin{array}{l}\text { Apakah materi yang disajikan melalui LKS Ilmu } \\
\text { Pengetahuan Alam ini dapat memberikan } \\
\text { motivasi kepada peserta didik agar lebih giat }\end{array}$ & 4 & 4 & 100 & Valid & $\begin{array}{l}\text { Tidak } \\
\text { Revisi }\end{array}$ \\
\hline
\end{tabular}




\begin{tabular}{clcccccc}
\hline $\mathbf{9}$ & belajar? & $\begin{array}{l}\text { Bagaimanakah tingkat kesukaran bahasa yang } \\
\text { digunakan, apakah sesuai dengan tingkat } \\
\text { pemahaman peserta didik? }\end{array}$ & 4 & 4 & 100 & Valid & $\begin{array}{c}\text { Tidak } \\
\text { Revisi }\end{array}$ \\
\hline $\mathbf{1 0}$ & $\begin{array}{l}\text { Apakah instrumen evaluasi yang digunakan } \\
\text { dapat mengukur kemampuan peserta didik? }\end{array}$ & 4 & 4 & 100 & Valid & $\begin{array}{c}\text { Tidak } \\
\text { Revisi }\end{array}$ \\
\hline $\mathbf{1 1}$ & $\begin{array}{l}\text { Apakah pemilihan Al-Asma' Al-Husna yang } \\
\text { digunakan sesuai dengan materi? }\end{array}$ & 4 & 4 & 100 & Valid & $\begin{array}{c}\text { Tidak } \\
\text { Revisi }\end{array}$ \\
\hline $\mathbf{1 2}$ & $\begin{array}{l}\text { Apakah penjelasan antara Al-Asma' Al-Husna } \\
\text { terhadap materi sudah sesuai? }\end{array}$ & 3 & 4 & 75 & Valid & $\begin{array}{c}\text { Tidak } \\
\text { Revisi }\end{array}$ \\
\hline & Jumlah & $\mathbf{4 6}$ & $\mathbf{4 8}$ & $\mathbf{9 5 , 8}$ & Valid & $\begin{array}{c}\text { Tidak } \\
\text { Revisi }\end{array}$ \\
\hline
\end{tabular}

Tabel 1. Hasil Validasi oleh Ahli Materi

$$
\begin{aligned}
& \text { Keterangan: } \\
& \mathrm{P} \quad=\text { persentase yang dicari } \\
& \sum \mathrm{X} \quad \text { = total jawaban responden dalam } 1 \text { item } \\
& \sum \mathrm{X} 1 \quad \text { = jumlah jawaban tertinggi dalam } 1 \text { item }
\end{aligned}
$$

Berdasarkan tabel di atas, persentase hasil validasi yang diperoleh adalah 95,8\%. Apabila hasil validasi yang terhadap LKS dikembangkan memiliki nilai reliabilitas lebih besar daripada 75\% maka dinyatakan reliabel (Rahmi \& Wati, 2014). Dengan demikian hasil validasi terhadap pengembangan LKS Ilmu Pengetahuan Alam melalui pendekatan integrasi Al-Asma' Al-Husna menunjukkan

\begin{tabular}{|c|c|c|c|c|c|c|}
\hline \multirow{2}{*}{ No. } & \multirow{2}{*}{ Kriteria } & \multicolumn{2}{|c|}{ Skor } & \multirow{2}{*}{ P (\%) } & \multirow{2}{*}{ Interpretasi } & \multirow{2}{*}{ Ket. } \\
\hline & & $\mathbf{X}$ & X1 & & & \\
\hline 1 & $\begin{array}{l}\text { Desain sampul depan sesuai } \\
\text { dengan materi }\end{array}$ & 3 & 4 & 75 & Cukup Valid & $\begin{array}{l}\text { Tidak } \\
\text { Revisi }\end{array}$ \\
\hline 2 & $\begin{array}{l}\text { Jenis huruf yang digunakan sesuai } \\
\text { dengan peserta didik Sekolah } \\
\text { Dasar kelas IV }\end{array}$ & 3 & 4 & 75 & Cukup Valid & $\begin{array}{l}\text { Tidak } \\
\text { Revisi }\end{array}$ \\
\hline 3 & $\begin{array}{l}\text { Ukuran huruf yang digunakan } \\
\text { sesuai dengan peserta didik } \\
\text { Sekolah Dasar kelas IV }\end{array}$ & 3 & 4 & 75 & Cukup Valid & $\begin{array}{l}\text { Tidak } \\
\text { Revisi }\end{array}$ \\
\hline 4 & $\begin{array}{l}\text { Gambar pada buku sesuai dengan } \\
\text { materi }\end{array}$ & 4 & 4 & 100 & Valid & $\begin{array}{l}\text { Tidak } \\
\text { Revisi }\end{array}$ \\
\hline 5 & $\begin{array}{l}\text { Gambar yang digunakan menarik } \\
\text { minat peserta didik }\end{array}$ & 3 & 4 & 75 & Cukup Valid & $\begin{array}{l}\text { Tidak } \\
\text { Revisi }\end{array}$ \\
\hline 6 & $\begin{array}{l}\text { Tata letak gambar menarik minat } \\
\text { peserta didik }\end{array}$ & 3 & 4 & 75 & Cukup Valid & $\begin{array}{l}\text { Tidak } \\
\text { Revisi }\end{array}$ \\
\hline 7 & Gambar pada lembar kerja peserta & 4 & 4 & 100 & Valid & Tidak \\
\hline
\end{tabular}
hasil yang valid.

Adapun hasil penilaian oleh ahli desain terhadap lembar kerja peserta didik IPA sebagai berikut: 


\begin{tabular}{clccccc}
\hline & $\begin{array}{l}\text { didik dekat dengan kehidupan } \\
\text { peserta didik }\end{array}$ & & & & & Revisi \\
\hline $\mathbf{8}$ & $\begin{array}{l}\text { Ukuran gambar pada lembar kerja } \\
\text { peserta didik tepat }\end{array}$ & \multirow{2}{*}{3} & 4 & 75 & Cukup Valid & $\begin{array}{c}\text { Tidak } \\
\text { Revisi }\end{array}$ \\
\hline $\mathbf{9}$ & Warna pada buku konsisten & 4 & 4 & \multirow{2}{*}{100} & Valid & $\begin{array}{c}\text { Tidak } \\
\text { Revisi }\end{array}$ \\
\hline $\mathbf{1 0}$ & Layout pada buku menarik & 4 & 4 & \multirow{2}{*}{100} & Valid & $\begin{array}{c}\text { Tidak } \\
\text { Revisi }\end{array}$ \\
\hline Jumlah & $\mathbf{3 4}$ & $\mathbf{4 0}$ & $\mathbf{8 5}$ & Valid & Tidak Revisi & Jumlah \\
\hline
\end{tabular}

Tabel 2. Hasil Validasi oleh Ahli Desain

\author{
Keterangan: \\ $\mathrm{P} \quad=$ persentase yang dicari \\ $\sum \mathrm{X}=$ total jawaban responden dalam 1 item \\ $\sum \mathrm{X} 1=$ jumlah jawaban tertinggi dalam 1 item
}

Hasil penilaian oleh ahli desain juga menyatakan valid dengan persentase sebesar 85,0\%. Dengan demikian desain pada LKS tersebut juga dinyatakan layak oleh ahli desain untuk digunakan sebagai bahan ajar yang menarik bagi peserta didik.

Berdasarkan kedua hasil validasi di atas, baik hasil validasi materi maupun hasil validasi desain memperoleh hasil validitas yang baik. Dengan demikian, maka kedua ahli tersebut menyatakan kelayakan terhadap LKS Ilmu Pengetahuan Alam melalui pendekatan integrasi Al-Asma' Al-Husna.

\title{
3. Uji Kemenarikan LKS IPA melalui pendekatan integrasi Al-Asma' Al-Husna
}

Penilaian terhadap kemenarikan LKS juga dilakukan dengan responden adalah 26 peserta didik kelas IV SDI Salafiyah Khairudin Kecamatan Gondanglegi Kabupaten Malang. Penilaian uji kemenarikan dilakukan melalui angket dengan 10 butir pertanyaan. Adapun penilaian uji kemenarikan disajikan pada tabel berikut:

\begin{tabular}{|c|c|c|c|c|c|c|c|c|c|c|c|c|c|}
\hline \multirow{2}{*}{$\begin{array}{c}\text { Peserta } \\
\text { Didik }\end{array}$} & \multicolumn{10}{|c|}{ Aspek Penilaian } & \multirow[t]{2}{*}{$\Sigma \mathbf{n}$} & \multirow[t]{2}{*}{$\mathbf{X 1}$} & \multirow[t]{2}{*}{$\%$} \\
\hline & 1 & 2 & 3 & 4 & 5 & 6 & 7 & 8 & 9 & 10 & & & \\
\hline X1 & 4 & 4 & 4 & 4 & 4 & 3 & 4 & 4 & 4 & 1 & 36 & 40 & 90 \\
\hline $\mathrm{X} 2$ & 4 & 3 & 4 & 3 & 4 & 3 & 4 & 4 & 4 & 2 & 35 & 40 & 87,5 \\
\hline X3 & 4 & 4 & 4 & 3 & 4 & 3 & 3 & 4 & 3 & 2 & 34 & 40 & 85 \\
\hline $\mathrm{X} 4$ & 4 & 4 & 4 & 4 & 4 & 4 & 4 & 4 & 4 & 4 & 40 & 40 & 100 \\
\hline $\mathrm{X5}$ & 4 & 4 & 3 & 3 & 4 & 3 & 3 & 4 & 4 & 2 & 34 & 40 & 85 \\
\hline X6 & 4 & 4 & 4 & 4 & 4 & 4 & 4 & 4 & 4 & 4 & 40 & 40 & 100 \\
\hline X7 & 3 & 3 & 3 & 3 & 4 & 3 & 2 & 4 & 3 & 2 & 30 & 40 & 75 \\
\hline X8 & 3 & 4 & 4 & 4 & 4 & 2 & 4 & 3 & 4 & 1 & 33 & 40 & 82,5 \\
\hline X9 & 1 & 3 & 3 & 3 & 4 & 3 & 3 & 3 & 3 & 2 & 28 & 40 & 70 \\
\hline $\mathrm{X} 10$ & 3 & 3 & 4 & 4 & 4 & 2 & 3 & 3 & 4 & 4 & 34 & 40 & 85 \\
\hline X11 & 3 & 4 & 4 & 3 & 4 & 3 & 3 & 4 & 3 & 4 & 35 & 40 & 87,5 \\
\hline
\end{tabular}




\begin{tabular}{|c|c|c|c|c|c|c|c|c|c|c|c|c|c|}
\hline $\mathrm{X} 12$ & 3 & 4 & 4 & 3 & 4 & 2 & 3 & 4 & 4 & 3 & 34 & 40 & 85 \\
\hline X13 & 4 & 4 & 4 & 3 & 4 & 3 & 3 & 4 & 3 & 4 & 36 & 40 & 90 \\
\hline X14 & 4 & 4 & 3 & 3 & 4 & 4 & 3 & 4 & 3 & 4 & 36 & 40 & 90 \\
\hline X15 & 4 & 4 & 4 & 3 & 4 & 4 & 4 & 4 & 4 & 4 & 39 & 40 & 97,5 \\
\hline X16 & 3 & 4 & 3 & 3 & 3 & 2 & 3 & 3 & 3 & 4 & 31 & 40 & 77,5 \\
\hline X17 & 3 & 3 & 4 & 3 & 4 & 4 & 3 & 3 & 3 & 2 & 32 & 40 & 80 \\
\hline X18 & 3 & 4 & 4 & 3 & 4 & 1 & 3 & 3 & 3 & 4 & 32 & 40 & 80 \\
\hline X19 & 4 & 4 & 4 & 4 & 4 & 3 & 4 & 4 & 3 & 4 & 38 & 40 & 95 \\
\hline X20 & 3 & 3 & 4 & 3 & 4 & 3 & 3 & 3 & 3 & 4 & 33 & 40 & 82,5 \\
\hline $\mathrm{X} 21$ & 3 & 4 & 3 & 3 & 4 & 3 & 4 & 4 & 4 & 3 & 35 & 40 & 87,5 \\
\hline $\mathrm{X} 22$ & 4 & 4 & 3 & 3 & 4 & 3 & 4 & 3 & 3 & 4 & 35 & 40 & 87,5 \\
\hline $\mathrm{X} 23$ & 4 & 4 & 4 & 3 & 4 & 3 & 4 & 4 & 4 & 3 & 37 & 40 & 92,5 \\
\hline $\mathrm{X} 24$ & 3 & 3 & 3 & 3 & 3 & 3 & 3 & 3 & 3 & 3 & 30 & 40 & 75 \\
\hline$\times 25$ & 4 & 4 & 4 & 4 & 4 & 4 & 4 & 4 & 4 & 2 & 38 & 40 & 95 \\
\hline $\mathrm{X} 26$ & 3 & 4 & 3 & 4 & 4 & 3 & 3 & 3 & 3 & 3 & 33 & 40 & 83 \\
\hline$\Sigma \mathrm{X}$ & 89 & 97 & 95 & 86 & 102 & 78 & 88 & 94 & 90 & 79 & 898 & - & - \\
\hline$\Sigma X 1$ & 108 & 108 & 108 & 108 & 108 & 108 & 108 & 108 & 108 & 108 & - & 1040 & - \\
\hline$\%$ & 82 & 90 & 88 & 80 & 94 & 72 & 81 & 87 & 83 & 73 & - & - & $86 \%$ \\
\hline
\end{tabular}

\section{Uji Efektivitas LKS IPA melalui pendekatan integrasi Al-Asma' Al-Husna}

Setelah LKS dinyatakan layak dalam aspek materi dan desain, maka LKS diuji coba kepada peserta didik untuk memastikan tingkat efektivitas dalam meningkatkan hasil belajar peserta didik. Uji coba dilakukan dengan metode eksperimen pre-test dan post-test. Adapun data hasil pre-test dan post-test sebagaimana tabel berikut.

\begin{tabular}{ccccc}
\hline No. & Peserta Didik & KKM & \multicolumn{2}{c}{ Skor } \\
\cline { 4 - 5 } & & & Pre-test (x) & Post-test (y) \\
\hline $\mathbf{1}$ & Peserta didik 1 & 75 & 72 & 75 \\
\hline $\mathbf{2}$ & Peserta didik 2 & 75 & 70 & 78 \\
\hline $\mathbf{3}$ & Peserta didik 3 & 75 & 76 & 72 \\
\hline $\mathbf{4}$ & Peserta didik 4 & 75 & 72 & 80 \\
\hline $\mathbf{5}$ & Peserta didik 5 & 75 & 66 & 73 \\
\hline $\mathbf{6}$ & Peserta didik 6 & 75 & 72 & 72 \\
\hline $\mathbf{7}$ & Peserta didik 7 & 75 & 76 & 76 \\
\hline $\mathbf{8}$ & Peserta didik 8 & 75 & 72 & 72 \\
\hline $\mathbf{9}$ & Peserta didik 9 & 75 & 72 & 73 \\
\hline $\mathbf{1 0}$ & Peserta didik 10 & 75 & 72 & 75 \\
\hline $\mathbf{1 1}$ & Peserta didik 11 & 75 & 72 & 72 \\
\hline $\mathbf{1 2}$ & Peserta didik 12 & 75 & 72 & 82 \\
\hline $\mathbf{1 3}$ & Peserta didik 13 & 75 & 80 & 67 \\
\hline $\mathbf{1 4}$ & Peserta didik 14 & 75 & 64 & 72 \\
\hline $\mathbf{1 5}$ & Peserta didik 15 & 75 & 70 & 74 \\
\hline $\mathbf{1 6}$ & Peserta didik 16 & 75 & 70 & \\
\hline $\mathbf{1 7}$ & Peserta didik 17 & 75 & 75 & 72 \\
\hline $\mathbf{1 8}$ & Peserta didik 18 & & 72 \\
\hline
\end{tabular}




\begin{tabular}{ccccc}
\hline $\mathbf{1 9}$ & Peserta didik 19 & 75 & 68 & 70 \\
\hline $\mathbf{2 0}$ & Peserta didik 20 & 75 & 64 & 66 \\
\hline $\mathbf{2 1}$ & Peserta didik 21 & 75 & 74 & 75 \\
\hline $\mathbf{2 2}$ & Peserta didik 22 & 75 & 68 & 68 \\
\hline $\mathbf{2 3}$ & Peserta didik 23 & 75 & 76 & 77 \\
\hline $\mathbf{2 4}$ & Peserta didik 24 & 75 & 78 & 80 \\
\hline $\mathbf{2 5}$ & Peserta didik 25 & 75 & 64 & 65 \\
\hline $\mathbf{2 6}$ & Peserta didik 26 & 75 & 64 & 64 \\
\hline & Rata-rata & & $\mathbf{7 1 , 5}$ & $\mathbf{7 2 , 8}$ \\
\hline
\end{tabular}

Tabel 4. Hasil Pre-Test dan Post-Test Uji Kelayakan LKS

Data pada tabel di atas dianalisis dengan menggunakan uji $\mathrm{T}$ untuk mengetahui pengaruh penggunaan LKS. Penghitungan uji T tersebut dilakukan dengan menggunakan aplikasi Microsoft Excel 2016. Adapun hasil analisis uji kelayakan LKS disajikan dalam tabel berikut.

t-Test: Paired Two Sample for Means

\begin{tabular}{lrr}
\hline & Pre-test (x) & Post-test (y) \\
\hline Mean & 71,46153846 & 88 \\
Variance & 21,29846154 & 106,16 \\
Observations & 26 & 26 \\
Pearson Correlation & 0,033648477 & \\
Hypothesized Mean Difference & 25 & \\
Df & & \\
t Stat & 7,565171808 & \\
P(T<=t) one-tail & $3,20456 \mathrm{E}-08$ & \\
t Critical one-tail & 1,708140761 & \\
P(T<=t) two-tail & $6,40912 \mathrm{E}-08$ & \\
t Critical two-tail & 2,059538553 & \\
\hline
\end{tabular}

Tabel 5. Analisis Uji Kelayakan LKS dengan Uji T Sampel Berpasangan

Berdasarkan paparan tabel di atas, diketahui Thitung adalah 7,565 dan Ttabel adalah 3,204. Dengan demikian, maka diperoleh hasil $\mathrm{T}_{\text {hitung }}>\mathrm{T}_{\text {tabel. }}$ Hal ini menunjukkan bahwasanya hasil pengujian tersebut menolak $\mathrm{H}_{0}$, "LKS IPA melalui pendekatan integrasi Al-Asma' Al-Husna tidak dapat meningkatkan prestasi belajar siswa kelas IV". Dengan ditolaknya $\mathrm{H}_{0}$, maka hasil tersebut menerima Ha, yaitu LKS IPA melalui pendekatan integrasi Al-Asma' Al-Husna dapat meningkatkan prestasi belajar siswa kelas IV. Hal tersebut menunjukkan 
bahwasanya LKS Ilmu Pengetahuan Alam melalui pendekatan integrasi Al-Asma' Al-Husna layak untuk digunakan sebagai sumber belajar oleh peserta didik.

LKS dikembangkan dengan tujuan memudahkan siswa dalam menerapkan prosedur kerja ilmiah guna mencari konsep pembelajaran yang diinginkan (Afifah, 2015). Peneliti melakukan pengembangan terhadap LKS Ilmu Pengetahuan alam melalui pendekatan Integrasi Al-Asma' Al-Husna selain untuk mempermudah siswa menerapkan prosedur kerja ilmiah, siswa juga dimudahkan dalam memahami keterkaitan antara konsep sains dan nilai-nilai spiritual keislaman khususnya pemahaman tentang Al-Asma' Al-Husna melalui pendekatan integrasi Al-Asma' Al-Husna.

\section{SIMPULAN}

LKS Ilmu Pengetahuan dikembangkan dengan menggunakan pendekatan integrasi Al-Asma' Al-Husna. LKS Ilmu Pengetahuan Alam melalui pendekatan AlAsma' Al-Husna terdiri atas 5 bagian, yaitu: (1) pra pendahuluan, (2) pendahuluan, (3) isi, (4) pelengkap, dan (5) penutup.

Hasil validasi terhadap LKS Ilmu Pengetahuan Alam melalui pendekatan AlAsma' Al-Husna oleh ahli materi dan LKS Ilmu Pengetahuan Alam melalui pendekatan integrasi Al-Asma' Al-Husna telah divalidasi oleh ahli materi dan ahli desain. Hasil kedua validasi tersebut menyatakan valid terhadap LKS Ilmu Pengetahuan Alam melalui pendekatan Al-Asma' Al-Husna, sehingga LKS Ilmu Pengetahuan Alam melalui pendekatan Al-Asma' Al-Husna layak digunakan sebagai salah satu sumber belajar.

LKS Ilmu Pengetahuan Alam melalui pendekatan integrasi Al-Asma' Al-Husna telah dinyatakan efektif dalam meningkatkan prestasi belajar siswa. Hal ini dibuktikan dengan hasil uji coba kepada siswa, di mana hasil tersebut telah dianalisis dan menunjukkan peningkatan yang signifikan. Oleh karena itu, LKS Ilmu Pengetahuan Alam melalui pendekatan integrasi Al-Asma' Al-Husna dinyatakan layak untuk digunakan sebagai salah satu sumber belajar oleh peserta didik.

\section{DAFTAR RUJUKAN}

Afifah, R. N. (2015). Pengembangan Lembar Kerja Siswa (LKS) Ilmu Pengetahuan Alam Berbasis Metode Percobaan. Universitas PGRI Yogyakarta.

Anggraini, R., Wahyuni, S., \& Lesmono, A. D. (2016). Pengembangan lembar kerja siswa (Lks) berbasis keterampilan proses di SMAN 4 Jember. Jurnal Pembelajaran Fisika, 4(4), 350-365. 
Bahri, S., \& Nidal, A. (2019). Human Communication with God through Asmaul Husna (99 Names of Allah)(Study of Asmaul Husna's Understanding in Islamic Theology). Britain International of Humanities and Social Sciences (BioHS) Journal, 1(2), 140-148.

Fannie, R. D., \& Rohati, R. (2014). Pengembangan lembar kerja siswa (LKS) berbasis POE (predict, observe, explain) pada materi program linear kelas XII SMA. Sainmatika: Jurnal Sains Dan Matematika Universitas Jambi, 8(1), 221053.

Hamdu, G., \& Agustina, L. (2011). Pengaruh motivasi belajar siswa terhadap prestasi belajar IPA di sekolah dasar. Jurnal Penelitian Pendidikan, 12(1), 9096.

Latifah, S., Hidayah, N., Shawmi, A. N., Amrullah, M. A., \& Fitriana, N. S. (2019). Snake and ladder game integrated with Asmaul-Husna: Development of learning media. Journal of Physics: Conference Series, 1155(1), 012024. IOP Publishing.

Nannyonjo, H. (2007). Education inputs in Uganda: An analysis offactors influencing learning achievement in grade six. The World Bank.

Pribadi, B. A. (2010). Model Desain Sistem Pembelajaran. Jakarta: Dian Rakyat.

Rahmi, R., \& Wati, M. (2014). Pengembangan lembar kerja siswa (LKS) berbasis inkuiri terbimbing dan multimedia pembelajaran IPA SMP. Berkala Ilmiah Pendidikan Fisika, 2(2), 173-184.

Rosmani, A. F., \& Zakaria, M. (2018). Asmaul Husna Learning through Gamifications and Adaptation of Signalling Principle. Journal of Physics: Conference Series, 1019(012080), 1-7.

Sadjati, I. M. (2012). Pengembangan bahan ajar. In Hakikat Bahan Ajar (pp. 1-62). Universitas Terbuka. Retrieved from http://repository.ut.ac.id/id/eprint/4157

Saleh, I., \& Kim, S. (2009). A fuzzy system for evaluating students' learning achievement. Expert Systems with Applications, 36(3), 6236-6243.

Setyosari, H. P. (2016). Metode penelitian pendidikan \& pengembangan. Jakarta: Kencana Prenada Media.

Sugiyono. (2009). Metode Penelitian Pendidikan Pendekatan Kuantitatif, Kualitatif, dan $R \& D$. Bandung: Alfabeta. 
Sukmadinata, N. S. (2008). Metode Penelitian Pendidikan. Bandung: Remaja Rosdakarya.

Tarigan, B. N. B., Agung, A. A. G., \& Parmiti, D. P. (2019). Pengembangan lembar kerja siswa (lks) bermuatan karakter untuk meningkatkan hasil belajar ipa. Journal of Education Technology, 3(3), 179-185.

Widjajanti, E. (2008). Kualitas lembar kerja siswa. Makalah Seminar Pelatihan Penyusunan LKS Untuk Guru SMK/MAK Pada Kegiatan Pengabdian Kepada Masyarakat Jurusan Pendidikan FMIPA Universitas Negeri Yogyakarta, 2-5. 